\title{
PEMENUHAN KEBUTUHAN PENDIDIKAN ANAK ASUH DI PANTI SOSIAL ASUHAN ANAK
}

\author{
Oleh: \\ Sella Khoirunnisa, Ishartono \& Risna Resnawaty
}

\begin{abstract}
ABSTRAK
Pendidikan pada dasarnya merupakan hak dari setiap anak tanpa terkecuali. Namun kenyataan yang ditemukan di lapangan, pemenuhan kebutuhan pendidikan bagi anak tidak semudah yang dibayangkan. Hal ini dikarenakan tidak semua anak beruntung dilahirkan ditengah keluarga yang mampu secara fisik maupun finansial dalam memenuhi segala kebutuhan anak, beberapa anak justru terlahir di tengah keluarga dengan kehidupan yang serba berkekurangan sehingga tidak dapat menjamin terpenuhinya segala kebutuhan anak dan kesejahteraan anak. Keterbatasan tersebut mendorong anak untuk mengalami pengasuhan di luar keluarga, salah satu lembaga pelayanan sosial yang memang didesain khusus sebagai alternatif pengasuhan anak ialah panti sosial asuhan anak. Namun demikian keberadaan panti asuhan kerap dilanda berbagai issue terkait keterbatasan pelayanan panti asuhan seperti tidak adanya sumber dana tetap, keterbatasan fasilitas, dan kekurangan tenaga profesional seringkali menyertai keberadaan lembaga pelayanan sosial anak ini. Merujuk pada beberapa hasil penelitian menunjukan bahwa pemenuhan hak dan kebutuhan pendidikan anak di panti asuhan belum maksimal dikarenakan seringkali terbentur dengan masalah pendanaan dari donatur yang tidak tetap, disisi lain anak panti juga seringkali mengalami kekurangan perhatiam dan kasih sayang dikarenakan jumlah pengasuh di panti yang hanya sedikit sehingga pendidikan anak panti seringkali tertinggal dibanding anak seusia mereka yang mengalami pengasuhan di dalam keluarga.
\end{abstract}

Kata Kunci: Pendidikan, Anak Asuh, Panti Sosial Asuhan Anak

\section{Pendahuluan}

Indonesia merupakan negara berkembang dengan jumlah penduduk terpadat ke-empat di dunia. Hasil proyeksi Sensus Penduduk 2010, pada tahun 2011 penduduk Indonesia diperkirakan mencapai 243,8 juta jiwa. Sekitar 33,9\% dari penduduk Indonesia adalah anak-anak berusia 0-17 tahun. Hal ini menunjukan bahwa berinvestasi untuk anak-anak Indonesia sama dengan berinvestasi dengan sepertiga lebih penduduk Indonesia.

Gambaran kondisi anak menjadi dasar penentuan kebijakan yang baik dan tepat bagi anak. Mengingat periode anak merupakan periode yang tepat untuk lebih menggali dan mengasah potensi anak agar dapat dikembangkan. Anak merupakan kelompok yang perlu disiapkan secara matang untuk kemajuan di masa depan.

Indikator yang utama untuk menilai kualitas anak ialah dari bidang pendidikan. Hasil Susenas 2011 menunjukan bahwa anak berusia sekolah yakni usia 5-17 tahun yang berstatus sekolah ialah sebesar 80,29\%. Pada kelompok usia yang sama terdapat sebesar 7,36\% yang berstatus tidak sekolah lagi, serta $12,35 \%$ lainnya belum pernah sekolah. Kenyataan ini memprihatinkan mengingat meskipun persentase anak yang memiliki status bersekolah lebih besar, namun masih ditemukan sejumlah anak yang belum pernah sekolah pada kategori usia yang sama. 
Pada hakikatnya semua anak memiliki hak yang sama untuk tumbuh dan berkembang, termasuk hak dalam menerima pendidikan formal. Adanya sejumlah anak yang ditemukan belum pernah sekolah umumnya dilatarbelakangi oleh beberapa faktor seperti penelantaran, kemiskinan, dan tidak memiliki orang tua atau keluarga lagi. Hal ini berdampak pada kehilangan tanggungjawab pengasuhan bagi anak, sehingga anak tidak dapat berkembang sebagaimana mestinya.

Dalam menanggapi fenomena ini, perlu adanya perhatian khusus bagi anak yang mengalami masalah sosial agar anak tidak terjebak pada kasus-kasus kekerasan, pelanggaran hukum, dan eksploitasi. Maka dari itu dibentuklah suatu wadah atau lembaga yang siap mewadahi anak-anak kurang beruntung agar tetap dapat terpenuhi hak nya, sehingga dapat tumbuh dan berkembang secara wajar. Lembaga yang dimaksud salah satunya ialah Panti Sosial Asuhan Anak.

Keberadaan panti sosial asuhan anak berbanding lurus dengan meningkatnya jumlah anak terlantar beberapa tahun terakhir (Teja: 2014). Disisi lain, pengawasan dari pemerintah masih sangat kurang. Berdampak pada seringkali ditemukan kualitas pelayanan di panti sosial asuhan anak yang masih sangat terbatas.

Anak asuh seringkali dianggap memiliki status sosial yang rendah di masyarakat luas, karena panti asuhan dianggap sebagai tempat meminta belas kasihan orang (Mazaya dan Supradewi: 2011). Anak asuh yang berada di panti sosial asuhan anak memiliki berbagai macam latarbelakang, pengalaman yang dibawa mereka dari berbagai lingkungan yang pernah dialami akan berdampak pada pembentukan psikologi dan sosialnya. Fenomena diatas memberikan gambaran kondisi anak asuh. Diperlukan adanya penanganan dan pengasuhan yang tepat untuk mengatasi kondisi ini.

Panti sosial asuhan anak sebagai lembaga yang mewadahi anak asuh memberikan pelayanan sosial guna memperbaiki keberfungsian anak dan kualitas kesejahteraannya. Pelayan diberikan dalam konteks memenuhi kebutuhan anak agar anak dapat mandiri di masa depan. Pelayanan ini ditujukan bagi masyarakat yang mengalami keterbatasan khususnya dalan bidang ekonomi, sehingga tidak mampu mengasuh dan memenuhi kebutuhan tumbuh kembang anak.

\section{Panti Sosial Asuhan Anak}

Permasalahan anak yang semakin kompleks menuntut dibentuknya suatu wadah yang mampu menjamin terpenuhinya kebutuhan anak akan pengasuhan, pelayanan, dan pembinaan, yang diwujudkan dalam bentuk panti. Syarif Muhidin (1992: 3) menyatakan bahwa, panti merupakan suatu tempat dalam memberikan pembinaan dan pelayanan sosial modern. Pernyataan tersebut mendukung keberadaan panti sebagai wadah terselenggaranya pelayanan sosial secara lebih sistematis di masyarakat.

Secara umum dalam Kepmensos No.50/HUK/2004 menjelaskan bahwa Panti Sosial Asuhan Anak adalah :

"Panti sosial yang mempunyai tugas memberikan bimbingan dan pelayanan bagi anak yatim, piatu, yatim piatu, anak yang kurang mampu, dan terlantar agar potensi dan kapasitas belajarnya pulih kembali dan dapat berkembang secara wajar.”

Panti Sosial Asuhan Anak juga memegang fungsi yang harus dijalankan dalam penyelenggaraannya, fungsi-fungsi tersebut terwujud dalam program dan pelayanan yang diberikan oleh panti. Menurut Departemen Sosial Republik Indonesia panti asuhan mempunyai fungsi sebagai berikut:

1. Sebagai lembaga pelayanan kesejahteraan bagi anak dan melaksanakan pengasuhan alternatif pengganti orang tua.

Pengasuhan alternatif merupakan pengasuhan berbasis keluarga pengganti yang dilaksanakan oleh pihak-pihak di luar keluarga inti atau kerabat anak. Pengasuhan alternatif yang diselenggarakan lembaga/panti asuhan harus diprioritaskan untuk menyediakan lingkungan 
yang dapat memenuhi kebutuhan kasih sayang anak, kelekatan (attachment), dan permanensi melalui keluarga pengganti.

2. Sebagai Pusat Pelayanan Kesejahteraan Sosial Anak

Panti asuhan berfungsi sebagai pemulihan, perlindungan, pengembangan, dan pencegahan. Fungsi pemulihan dan pengentasan anak ditujukan untuk mengembalikan dan menanamkan fungsi sosial anak asuh. Fungsi perlindungan merupakan fungsi yang menghindarkan anak dari keterlambatan dan perlakuan kejam, fungsi ini diarahkan pula bagi keluarga-keluarga dalam rangka meningkatkan kemampuan keluarga untuk mengasuh dan melindungi keluarga dari kemungkinan terjadinya perpecahan. Fungsi pengembangan menekankan pada pengembangan potensi dan kemampuan anak asuh dan bukan penyembuhan dalam arti lebih menekankan pada pengembangan kemampuannya untuk mengembangkan diri sendiri sesuai dengan situasi dan kondisi lingkungan. Sedangkan fungsi pencegahan menitikberatkan pada intervensi terhadap lingkungan sosial anak asuh yang bertujuan di satu pihak dapat menghindarkan anak asuh dari pola tingkah laku yang sifatnya menyimpang, di lain pihak mendorong lingkungan sosial untuk mengembangkan pola-pola tingkah laku yang wajar.

3. Sebagai Pusat Data dan Informasi Serta Konsultasi Kesejahteraan Sosial Anak.

Dalam jangka panjang, Panti Asuhan diharapkan melakukan kegiatan:

a. Menentukan, menemukan, menghimpun, mengklasifikasi, dan menyimpan data secara sistematik yang berkaitan dengan kebutuhan, masalah, kemampuan, dan peranan anak dan remaja yang mengalami keterlantaran.

b. Membantu pemecahan masalah kerawanan sosial dalam lingkungan melalui pertemuan kasus di dalam maupun di luar panti, seperti seminar loka karya.

c. Menyebarkan informasi yang bertujuan untuk penyempurnaan kebijaksanaan dan program pelayanan kesejahteraan sosial anak, pengembangan ilmu pengetahuan terutama bagi Perguruan Tinggi, dan peningkatan kesadaran, tanggungjawab, dukungan, dan kesempatan bersama warga masyarakat.

4. Sebagai Pusat Pengembangan Keterampilan.

Panti Asuhan diharapkan melaksanakan pendidikan dan latihan keterampilan di dalam dan di luar panti yang bertujuan menumbuhkan usaha ekonomis produktif.

Dari pemaparan sebelumnya mengenai fungsi panti dapat disimpulkan bahwa Panti Asuhan Sosial Anak memiliki fungsi pengasuhan, pelayanan, pusat data dan informasi kesejahteraan sosial anak. Fungsi ini merupakan landasan dalam operasional panti agar lebih terarah, serta menunjang tercapainya tujuan dari penyelenggaraan Panti Sosial Asuhan Anak.

\section{Kebutuhan Pendidikan Anak Asuh}

Anak asuh dipahami sebagai anak yang membutuhkan pengasuhan alternatif diluar keluarga melalui lembaga atau panti asuhan. Hal ini dilakukan agar anak dapat tetap terpenuhi kebutuhan dasar dan hak-haknya. Dengan demikian diharapkan anak tidak terjerat dalam permasalahan sosial seperti penelantaran, pembuangan, dan eksploitasi anak.

Anak yang layak menjadi anak asuh ialah anak yang berada pada situasi sebagai berikut:

a. Keluarga anak tidak memberikan pengasuhan yang memadai sekalipun dengan dukungan yang sesuai, mengabaikan, atau melepaskan tanggung jawab terhadap anaknya.

b. Anak yang tidak memiliki keluarga atau keberadaan keluarga atau kerabat tidak diketahui.

c. Anak yang menjadi korban kekerasan, perlakuan salah, penelantaran, atau eksploitasi, sehingga demi keselamatan dan kesejahteraan diri mereka, pengasuhan dalam keluarga justru bertentangan dengan kepentingan terbaik anak.

d. Anak yang terpisah dari keluarga karena bencana, baik konflik sosial maupun bencana alam. 
Kriteria yang dijelaskan diatas dijadikan sebagai landasan dalam menilai sesuai atau tidaknya seorang anak berada dibawah pengasuhan lembaga atau panti asuhan. Anak yang lebih diprioritaskan dalam menerima alternatif pengasuhan di panti ialah anak yang memiliki permasalahan di bidang sosial dan ekonomi sehingga anak tersebut memiliki keterbatasan dan ketidakberdayaan yang dapat mengancam perkembangan anak.

Upaya untuk mencerdaskan bangsa berarti meningkatkan kualitas manusia Indonesia yang pada dasarnya dapat direalisasikan melalui kegiatan pendidikan termasuk proses belajar mengajar di sekolah. Salah satu keberhasilan anak asuh dalam pendidikan ditunjukkan dengan prestasi akademiknya. Pada kenyataannya ditemukan tuntutan prestasi akademik pada siswa semakin tinggi sementara daya belajarnya biasa-biasa saja. Hal inilah yang menyebabkan tingkat keberhasilan siswa dalam prestasi akademik kurang sebagaimana diharapkan oleh sekolah, orang tua dan siswa itu sendiri.

Fungsi pendidikan salah satunya adalah membentuk sikap dan orientasi siswa terhadap belajar, menanamkan sikap positif dan haus akan pengetahuan serta untuk mengembangkan keterampilan belajar secara efektif. Keberhasilan siswa dalam pendidikannya juga dipengaruhi oleh motivasi berprestasi yang dimiliki. Motivasi berprestasi sebagai daya dorong yang memungkinkan seseorang berhasil mencapai apa yang diidamkan. Seseorang yang memiliki motivasi berprestasi tinggi cenderung untuk selalu berusaha mencapai apa yang diinginkan walaupun mengalami hambatan dan kesulitan dalam meraihnya. Pada kenyataannya motivasi berprestasi yang dimiliki oleh seseorang cenderung sering mengalami penurunan dan di waktu lain mengalami peningkatan. Motivasi berprestasi yang dimiliki seseorang idealnya selalu mengalami progresif atau kemajuan sehingga akan mempercepat apa yang diidamkan. Hal inilah yang belum dimiliki oleh generasi muda untuk selalu meningkat motivasi berprestasi.

Pengurus panti asuhan dalam melaksanakan perannya dalam menunjang keberlanjutan pendidikan anak yang mana peran pengurus di panti asuhan adalah sebagai keluarga dan orang tua asuh bagi anak-anak asuh di panti asuhan. Kemudian peran pengurus panti asuhan selain sebagai pengganti keluarga dari anak-anak, pengurus juga mempunyai peran sebagai pembentuk watak, mental spiritual anak yang bertujuan membimbing, mendidik, mengarahkan, dan mengatur perilaku anak-anak asuh, sebagaimana yang diungkapkan oleh Sofiyatun (2012: 16) bahwa: Begitu pentingnya peran keluarga dalam perkembangan dan pertumbuhan anak maka fungsi keluarga haruslah tercukupi agar perkembangan serta pertumbuhan anak dapat berkembang dengan baik dan tidak terjerumus kepada hal-hal yang tidak diinginkan. Sedangkan Peranan Pengurus Panti Asuhan adalah mencoba menggantikan funngsi keluarga yang telah gagal dan kehilangan perannya sebagai pembentuk watak, mental spiritual anak yang bertujuan membimbing, mendidik, mengarahkan, dan mengatur perilaku anak-anak asuhnya agar menjadi seseorang yang mandiri dan berguna bagi masyarakat, bangsa dan negara.

Peran yang didapat anak asuh dari pengurus penti asuhan adalah peran sebagai orang tua asuh sebagi pengganti peran orang tua mereka yang mana pengurus panti asuhan berperan sebagai pendorong (motivasi) yaitu sebagai penyemangat anak untuk terus belajar dan memaknai pentingnya ilmu yang didapat; fasilitator adalah melengkapi/memenuhi keperluan anak asuh seperti fasilitas belajar, alat-alat belajar, sarana transportasi, serta anak-anak diberi kebebasan dalam menentukan sekolah yang mereka inginkan dan tentunya disesuaikan lagi dengan nilai yang mereka miliki; dan pembimbing yaitu berperan sebagai panutan bagi anak dalam melakukan segala hal. Dengan peran sebagai orang tua asuh, pengurus berusaha memberikan sesuatu yang baik bagi mereka yaitu dengan memberikan mereka fasilitas pendidikan, mengajarkan akan kemandirian, mengajarkan untuk saling menghormati baik sesama anak-anak di panti maupun dengan orang yang lebih tua seperti pengurus panti asuhan, serta melatih dan memberikan pelatihan keterampilan bagi anak asuh.

Sedangkan permasalahan yang dihadapi pertama yaitu permasalahan yang berasal dari diri pribadi anak, dari sekian banyak anak yang ada dalam panti asuhan semuanya berasal dari keluarga 
yang berbeda dengan latar belakang asing-masing. Hal ini lah yang menimbulkan perbedaan pada anak baik dalam tingkah laku, sifat maupun kecerdasan dari masing-masing anak. Terkadang tidak ada kecocokan antara anak yang satu dengan anak yang lain, kemudian menimbulkan keminderan pada anak yang merasa tertinggal dalam hal pendidikan dari teman-temannya, selain itu perbedaan tingkah laku anak sering menimbulkan ketidakcocokan sehingga terkadang menimbulkan perselisihan antara anak yang satu dengan yang lain. Tidak hanya itu, tidak semua anak mengerti dengan tugas sudah masing-masing dari mereka dapat misalnya masalah kebersihan yang paling terutama.

Kemudian untuk masalah kedua yaitu permasalahan yang timbul dari faktor dana. Dalam menjalankan segala kegiatan di panti asuhan, utamanya dalam hal makan, pakaian, pendidikan untuk anak-anak asuh dibutuhkan biaya yang besar dan terus menerus. Sumber dana pada panti asuhan berasal dari berbagai pihak diantaranya sumbangan rutin dari pemerintah dan adanya donatur-donatur yang peduli pada mereka. Sumbangan yang ada dari pemerintah dirasa terlalu minim atau belum mencukupi jika disesuaikan dengan kondisi yang ada saat ini.

\section{Penutup}

Panti sosial asuhan anak dalam penyelenggaraannya menjalankan fungsi pengasuhan pengganti orang tua, yang mana didalamnya terdapat fungsi pemenuhan kebutuhan pendidikan anak. Dalam penyelenggaraannya sebagian besar anak asuh yang berada di panti asuhan merupakan anak yang berasal dari keluarga yang tidak mampu, sehingga keinginan untuk melanjutkan pendidikan lah yang melatarbelakangi anak mengalami pengasuhan di panti asuhan.

Dalam upaya memenuhi kebutuhan pendidikan anak, panti sosial asuhan anak memberikan pendidikan formal di sekolah, kursus keterampilan, serta memberikan bimbingan belajar dalam lingkungan panti. Disisi lain panti sosial asuhan anak juga bertanggungjawab dalam memenuhi kebutuhan pokok anak yakni kebutuhan sandang, pangan, dan papan. Dengan demikian diharapkan dapat menunjang tumbuh dan kembang anak secara layak.

Secara umum pengurus panti melakukan upaya pemenuhan hak dan kebutuhan anak sesuai dengan hak yang didapatkan anak dalam keluarganya sendiri baik secara formal dan informal. Hal ini dilakukan untuk mewujudkan kemandirian anak di masyarakat dan memperbaiki kualitas kesejahteraan anak di masa depan.

\section{DAFTAR RUJUKAN}

Mazaya; Supradewi. 2011. Hubungan Konsep Diri dan Kebermaknaan Hidup Remaja Panti Asihan. Vol.6 (2) hal 104.

Mustika Sari, dkk. 2009. Peranan Panti Asuhan dalam Menunjang Pendidikan Anak. Sumatera Barat. Nuriqrima; Sulistyarini; Izhar. 2012. Peran Pengurus Panti Asuhan Dalam Menunjang Keberlanjutan

Pendidikan Anak di Panti Asuhan Nurul Hamid. UNTAN

Slavin, E Robert. 2008. Psikologi Pendidikan

Sugiyanto. Pentingnya Motivasi Berprestasi Dalam Mencapai Keberhasilan Akademik Siswa. UNY. Yogyakarta

Teja, Mohammad. 2014. Perlindungan Terhadap Anak Terlantar di Panti Asuhan. Vol. VI No. 05/I/P3DI/Maret/2014. Hal 09. 